\title{
Supplementation of increasing amounts of linseed oil to dairy cows fed total mixed rations: Effects on digestion, ruminal fermentation characteristics, protozoal populations, and milk fatty acid composition
}

\author{
C. Benchaar, ${ }^{\star 1}$ G. A. Romero-Pérez, ${ }^{\star}$ P. Y. Chouinard,† F. Hassanat, ${ }^{*}$ M. Eugene, ${ }^{\star 2}{ }^{2}$ H. V. Petit, ${ }^{\star}$ and C. Côrtes ${ }^{\star 3}$ \\ ${ }^{*}$ Agriculture and Agri-Food Canada, Dairy and Swine Research and Development Centre, 2000 College Street, Sherbrooke, Quebec, \\ Canada J1M 0C8 \\ †Université Laval, Département des Sciences Animales, Québec, Québec, Canada G1V 0A6
}

\begin{abstract}
The effect of linseed oil (LO) supplementation on nutrient digestibility, forage (i.e., timothy hay) in sacco ruminal degradation, ruminal fermentation characteristics, protozoal populations, milk production, and milk fatty acid (FA) profile in dairy cows was investigated. Four ruminally cannulated, primiparous lactating cows were used in a $4 \times 4$ Latin square design (28-d periods). They were fed a total mixed ration (50:50 forage:concentrate $(\mathrm{F}: \mathrm{C})$ ratio [dry matter $(\mathrm{DM})$ basis] without supplementation (control, CTL), or supplemented (wt/wt; DM basis) with LO at 2, 3, or 4\%. Supplementation with LO had no effect on DM intake (19 $\mathrm{kg} / \mathrm{d}$ ) and apparent total-tract digestibility of nutrients (organic matter, neutral detergent fiber, acid detergent fiber, starch, and gross energy). Ruminal $\mathrm{pH}$, ammonia, and total volatile FA concentrations were not changed by LO supplementation to diets. Extent of changes in volatile FA pattern and effective ruminal degradability of DM of timothy hay were minor. Neither the total numbers nor the genera distribution of protozoa was changed by the addition of increasing amounts of LO to the diet. Milk yield increased linearly $(26.1,27.3$, 27.4 , and $28.4 \mathrm{~kg} / \mathrm{d}$ for CTL to $\mathrm{LO} 4$, respectively) as the amount of LO added to the diet increased. Milk fat content was not affected by LO supplementation, whereas milk protein content decreased linearly with increasing amounts of LO in the diet. Milk fat proportions of several intermediates of ruminal biohydrogenation of polyunsaturated FA (i.e., trans-10 18:1, trans-11 18:1, cis-9,trans-11 18:2, trans-11,cis-15 18:2, and cis-9,trans-11,cis-15 18:3) increased linearly with LO
\end{abstract}

Received February 21, 2012.

Accepted April 15, 2012.

${ }^{1}$ Corresponding author: chaouki.benchaar@agr.gc.ca

${ }^{2}$ Current address: Institut National de la Recherche Agronomique, F-63122 Saint-Genès-Champanelle, France.

${ }^{3}$ Current address: Département de Productions Animales. École Supérieure d'Agriculture d'Angers, Angers, 49007, France. addition to the diet. The proportion of cis-9, cis-12 18:2 decreased linearly $(2.06,1.99,1.91$, and $1.83 \%$ for CTL to $\mathrm{LO} 4$, respectively) as the amount of LO in the diet increased. Milk fat content of cis-9,cis-12,cis-15 18:3 increased as the level of LO in the diet increased up to $3 \%$ but no further increase was observed when $4 \%$ of LO was fed $(0.33,0.79,0.86$, and $0.86 \%$ for CTL to LO4, respectively). A similar quadratic response to LO supplementation was also observed for cis-5, cis-8, cis11,cis-14,cis-17 20:5 and cis-5,cis-7,cis-10,cis-13,cis-16 $22: 5$. The results of the present study show that LO can be safely supplemented up to $4 \%$ in forage-based diets of dairy cows to enrich milk with potential health beneficial FA (i.e., n-3 FA) without causing any detrimental effects on rumen function, digestion, and milk production.

Key words: linseed oil, digestion, ruminal fermentation, milk fatty acid

\section{INTRODUCTION}

The inclusion of saturated fats of animal origin in human diets may increase the risk for cardiovascular diseases (Joyce et al., 2009). It has been estimated that dairy products contribute up to $60 \%$ of SFA to human diets in some European countries (Chilliard et al., 2007). Current public awareness on the health properties of PUFA, including $\alpha$-linolenic acid (18:3n-3) and conjugated linoleic acids (CLA), which are believed to improve human health, has increased the interest for dairy products rich in these FA (Hulshof et al., 1999).

Supplementing the diet of dairy cows with oil seeds and vegetable oils has been reported to enhance the contents of CLA and n-3 FA in milk (Chilliard et al., 2009). Linseed and linseed oil (LO) are rich sources of $18: 3 \mathrm{n}-3$, as it comprises 50 to $60 \%$ of their total FA content. Feeding different forms of linseed to grazing (Flowers et al., 2008) and confined (Loor et al., 2005; da Silva et al., 2007) dairy cows increased the concentration of n-3 FA and CLA in milk fat. Furthermore, extruded linseed has also been found to considerably 
increase 18:3n-3 and CLA in milk (Chilliard et al., 2009). Nevertheless, due to biohydrogenation, most unsaturated FA are converted to saturated fats before they leave the rumen (Griinari and Bauman, 1999). This process limits the content of unsaturated FA in milk and dairy products.

Past work also showed that supplementing ruminant diets with oil seed and vegetable oils had a negative effect on ruminal digestion of OM and feed intake (Jenkins, 1993; Martin et al., 2008). Such negative changes may limit the amount of LO that can be incorporated in the diet of dairy cows. Nonetheless, results have been conflicting among studies. For instance, Ueda et al. (2003) reported no negative effect of 3\% LO (on DM basis) supplementation on DMI and nutrient digestion in dairy cows, whereas Martin et al. (2008) observed a strong decrease in DMI and nutrient digestibility when $5.7 \%$ LO (DM basis) was added to the diet. Very few studies have investigated in the same experiment the effects of increasing amounts of LO on nutrient utilization, ruminal fermentation, and milk performance of dairy cows. Moreover, information on the effect of increasing levels of $\mathrm{LO}$ on ciliate protozoal populations is scarce. Therefore, the objective of the present study was to determine the effects of LO supplementation incorporated at different amounts into TMR of dairy cows on feed intake, digestion (total-tract and in sacco degradation), ruminal fermentation characteristics, protozoal counts, milk production, and milk composition, including FA profile.

\section{MATERIALS AND METHODS}

\section{Cows, Experimental Design, and Treatments}

Four primiparous lactating Holstein cows fitted with ruminal cannulas $(10 \mathrm{~cm}$; Bar Diamond Inc., Parma, ID) were used in a $4 \times 4$ Latin square design (28-d periods) balanced for carryover effects. The cows averaged $65 \pm 3$ DIM at the start of the experiment with an average $\mathrm{BW}$ of $566 \pm 32 \mathrm{~kg}$. They were housed in individual tie-stalls, milked twice daily (0730 and 1900 $\mathrm{h}$ ), and had free access to water during the experiment. Cows were fed for ad libitum intake $(5 \%$ orts, on asfed basis) a TMR without supplementation (control), or supplemented (DM basis) with LO (St. Lawrence Chemicals Inc., Baie d'Urfé, QC, Canada) at 2, 3, or $4 \%$. Ingredients and chemical composition of the diets are shown in Table 1. The appropriate amount of LO for each cow was weighed daily and mixed thoroughly with the TMR. Adaptation to experimental treatments was from $\mathrm{d} 1$ to 15 , in sacco ruminal degradability measurements from d 16 to 19 , ruminal sampling on d 20 , fecal sampling on d 21 to 26 , and milk sampling on d 21 to 28 . Cows were weighed at the beginning and the end of each experimental period on 2 consecutive days after the a.m. milking. Animals were cared for in accordance with the guidelines of the Canadian Council on Animal Care (Ottawa, ON, Canada; CCAC, 1993).

\section{Feed Intake and Apparent Total-Tract Digestibility}

Diets were offered in equal amounts twice daily (0830 and $1630 \mathrm{~h}$ ). Feed consumption was recorded daily by weighing feeds offered to and refused by the cows. Samples of the TMR, feed ingredients, and orts were collected daily and kept frozen. Samples were composited by cow within period, freeze dried, ground using a 1-mm screen Wiley mill (standard model 4; Arthur M. Thomas Co., Philadelphia, PA) and analyzed for DM, $\mathrm{OM}$, total N, NDF, ADF, starch, ether extract, and gross energy. Apparent total-tract digestibility of nutrients was determined using chromic oxide $\left(\mathrm{Cr}_{2} \mathrm{O}_{3}\right)$ as an inert external marker. On the last $10 \mathrm{~d}$ of each period, a gelatin capsule containing $10 \mathrm{~g}$ of the marker, providing approximately $2 \mathrm{~g}$ of $\mathrm{Cr}$, was inserted into the rumen of each cow daily. Fecal samples (100 g of wet weight) were collected twice daily at 0900 and $1600 \mathrm{~h}$ from the rectum of each cow on 5 consecutive days. The samples were composited by cow and period and immediately frozen $\left(-20^{\circ} \mathrm{C}\right)$. The pooled samples were subsequently freeze dried, ground through a 1-mm screen, and analyzed for DM, total N, OM, NDF, ADF, starch, gross energy, and Cr. An additional fecal sample (100 g of wet weight) was also collected from each cow before dosing the marker at each period. These samples were analyzed for DM and Cr concentrations. The $\mathrm{Cr}$ concentration in the feces taken before dosing was used to adjust for residual marker excretion. The Cr concentration in fecal samples obtained before dosing was in all cases less than $1 \%$ of the $\mathrm{Cr}$ concentration in the pooled fecal samples; thus, this adjustment was minimal.

Assuming the marker totally indigestible, the apparent digestibility of DM was calculated as follows: DM digestibility $=(1-\{[\mathrm{Cr}$ fed $(\mathrm{mg} / \mathrm{d})] /[\mathrm{DMI}(\mathrm{kg} / \mathrm{d}) \times \mathrm{Cr}$ in feces $(\mathrm{mg} / \mathrm{kg}$ of $\mathrm{DM})]\}) \times 100$, where DMI represents DM consumed during the 5-d fecal collection period. Digestibility of OM, CP, NDF, ADF, starch, and gross energy was calculated using the same approach with the corresponding intake for each nutrient.

\section{In Sacco Ruminal Degradability}

Ruminal degradability of timothy hay was determined using the nylon bag procedure. The hay was ground through a $2-\mathrm{mm}$ screen in a Wiley mill (standard model 
Table 1. Ingredients and chemical composition of the experimental diets

\begin{tabular}{|c|c|c|c|c|}
\hline \multirow[b]{2}{*}{ Composition } & \multicolumn{4}{|c|}{ Diet $^{1}$} \\
\hline & CTL & $\mathrm{LO} 2$ & LO3 & $\mathrm{LO} 4$ \\
\hline \multicolumn{5}{|l|}{ Ingredient, $\%$ of DM } \\
\hline Legume/grass silage & 24.3 & 24.3 & 24.3 & 24.3 \\
\hline Corn silage & 24.4 & 24.3 & 24.4 & 24.4 \\
\hline Corn, ground & 24.5 & 21.7 & 20.5 & 19.1 \\
\hline Barley, dry rolled & 8.0 & 8.0 & 8.0 & 8.0 \\
\hline Soybean meal & 6.6 & 6.1 & 6.1 & 6.2 \\
\hline Beet pulp, dehydrated & 4.1 & 4.1 & 4.1 & 4.2 \\
\hline Pelleted concentrate ${ }^{2}$ & 5.0 & 6.2 & 6.2 & 6.7 \\
\hline Linseed oil ${ }^{3}$ & 0.0 & 2.0 & 3.0 & 4.0 \\
\hline Vitamin-mineral premix ${ }^{4}$ & 2.6 & 2.5 & 2.6 & 2.6 \\
\hline Calcium carbonate & 0.6 & 0.6 & 0.6 & 0.6 \\
\hline \multicolumn{5}{|l|}{ Chemical composition } \\
\hline OM, $\%$ of $\mathrm{DM}$ & 92.6 & 92.8 & 92.7 & 92.8 \\
\hline $\mathrm{CP}, \%$ of $\mathrm{DM}$ & 17.3 & 17.0 & 16.8 & 17.0 \\
\hline NDF. $\%$ of DM & 29.7 & 28.8 & 29.4 & 28.9 \\
\hline $\mathrm{ADF}, \%$ of DM & 19.9 & 18.9 & 19.8 & 19.1 \\
\hline Starch, \% of DM & 20.7 & 20.5 & 18.9 & 18.8 \\
\hline Ether extract, \% of DM & 2.9 & 4.9 & 5.7 & 6.6 \\
\hline Gross energy, $\mathrm{kcal} / \mathrm{kg}$ of $\mathrm{DM}$ & 4,400 & 4,508 & 4,550 & 4,599 \\
\hline $\mathrm{NE}_{\mathrm{L}},{ }^{5} \mathrm{Mcal} / \mathrm{kg}$ of DM & 1.62 & 1.70 & 1.73 & 1.77 \\
\hline \multicolumn{5}{|l|}{$\mathrm{FA}, \mathrm{g} / \mathrm{kg}$ of $\mathrm{DM}$} \\
\hline $14: 0$ & 0.1 & 0.1 & 0.1 & 0.1 \\
\hline 16:0 & 4.5 & 5.5 & 5.9 & 6.1 \\
\hline $16: 1$ & 0.2 & 0.1 & 0.1 & 0.2 \\
\hline 18:0 & 0.5 & 1.3 & 1.6 & 1.9 \\
\hline cis-9 18:1 & 4.5 & 7.7 & 9.2 & 10.3 \\
\hline cis-11 18:1 & 0.1 & 0.3 & 0.4 & 0.4 \\
\hline cis-9,cis-12 18:2 & 12.3 & 15.0 & 16.4 & 17.1 \\
\hline cis-9,cis-12,cis-15 18:3 & 2.7 & 12.7 & 17.4 & 21.6 \\
\hline Total FA & 24.9 & 42.8 & 51.1 & 57.7 \\
\hline \multicolumn{5}{|c|}{$\begin{array}{l}{ }^{1} \mathrm{CTL}=\text { control TMR with no linseed oil; LO2 }=\text { TMR with } 2 \% \text { linseed oil; LO3 = TMR with } 3 \% \text { linseed oil; } \\
\text { LO } 4=\text { TMR with } 4 \% \text { linseed oil. }\end{array}$} \\
\hline \multirow{3}{*}{\multicolumn{5}{|c|}{$\begin{array}{l}{ }^{2} \text { Contained corn gluten meal }(20.8 \%) \text {, soybean meal Trituro (Soya Excel Inc., Beloeil, QC, Canada; } 28.3 \% \text { ) } \\
\text { canola meal (16.7\%), and corn distillers grain }(34.2 \%) \text {. } \\
{ }^{3} \text { Contained } 0.01 \% \text { butylated hydroxyanisole }(\mathrm{BHA}) \text { and } 0.01 \% \text { butylated hydroxytoluene (BHT). } \\
{ }^{4} \text { Contained (per kilogram) } 90.2 \mathrm{~g} \text { of } \mathrm{Ca}, 49.0 \mathrm{~g} \text { of P, } 48.9 \mathrm{~g} \text { of } \mathrm{Mg}, 17.6 \mathrm{~g} \text { of S, } 140 \mathrm{~g} \text { of Na, } 14.3 \mathrm{~g} \text { of K, } 2.07 \mathrm{~g} \\
\text { of Fe, } 1.9 \mathrm{~g} \text { of Mn, } 2.7 \mathrm{~g} \text { of } \mathrm{Zn}, 447 \mathrm{mg} \text { of } \mathrm{Cu}, 69 \mathrm{mg} \text { of } \mathrm{I}, 7 \mathrm{mg} \text { of Co, } 20 \mathrm{mg} \text { of Se, } 452 \mathrm{IU} \text { of vitamin A, } 58 \mathrm{IU} \\
\text { of vitamin D, and } 2,692 \mathrm{IU} \text { of vitamin E. }\end{array}$}} \\
\hline & & & & \\
\hline & & & & \\
\hline${ }^{5}$ Net energy for lactation acco & C (2001). & & & \\
\hline
\end{tabular}

4; Arthur M. Thomas Co.) and 5-g samples (DM basis) were weighed in duplicate in polyester bags $(17 \times 9$ $\mathrm{cm}$; $53-\mu \mathrm{m}$ pore size) made of monofilament PeCap polyester (Sefar Nitex; Sefar AG, Heiden, Switzerland). Bags were placed in large mesh $(20 \times 30-\mathrm{cm})$ retaining sacs with $3 \times 5$-mm pores that allowed ruminal fluid to circulate freely. Bags were soaked in $37^{\circ} \mathrm{C}$ water for 5 min before being placed in duplicate in the ventral sac of the rumen for $0,2,4,8,16,24,48,72$, and $96 \mathrm{~h}$. Upon removal from the rumen, bags were immediately immersed in ice water to impede microbial activity, thoroughly rinsed with cold tap water, and frozen at $-20^{\circ} \mathrm{C}$. Afterward, bags were thawed, washed in a domestic washing machine, and freeze dried. Bags and contents were weighed, and dried residues were ground through a 1-mm screen (1093 Cyclotec Sample
Mill; Foss Tecator AB, Höganäs, Sweden) and stored for subsequent determination of DM. Zero-time disappearance was obtained by washing unincubated bags in a similar manner.

Kinetics of ruminal degradation of DM was calculated using a nonlinear model (McDonald, 1981). The NLIN procedure of SAS (SAS Institute Inc., Cary, NC) was used to fit the following model:

$$
\mathrm{P}=\mathrm{a}+\mathrm{b}\left(1-\mathrm{e}^{-\mathrm{c}(\mathrm{t}-\mathrm{L})}\right) \text { for } t>\mathrm{L},
$$

where $\mathrm{P}=$ percentage of $\mathrm{DM}$ disappearance from the nylon bag at time $\mathrm{t}, \mathrm{a}=$ soluble fraction $(\%), \mathrm{b}=$ slowly degradable fraction $(\%), \mathrm{c}=$ fractional rate of disappearance of the $\mathrm{b}$ fraction $(/ \mathrm{h}), \mathrm{L}=$ lag time (hours), and $\mathrm{t}=$ time of incubation (h). 
The effective ruminal degradability (ERD) of DM was calculated using the equation

$$
\mathrm{ERD}=\mathrm{a}+[\mathrm{bc} /(\mathrm{c}+\mathrm{kp})] \times \mathrm{e}^{(-\mathrm{kpL})},
$$

where $\mathrm{kp}$ is the ruminal passage rate calculated using the equation developed by NRC (2001) for dry forages.

\section{Ruminal Fermentation Characteristics and Protozoa Enumeration}

Ruminal fluid was collected from the anterior dorsal, anterior ventral, medium ventral, posterior dorsal, and posterior ventral locations within the rumen at $0,1,2$, 4,6 , and $8 \mathrm{~h}$ after the a.m. feeding. Samples $(250 \mathrm{~mL} /$ site) were withdrawn using a syringe screwed to a stainless tube ending with a probe covered by a fine metal mesh (RT rumen fluid collection tube; Bar Diamond Inc.). Ruminal fluid $\mathrm{pH}$ was measured immediately after sampling (Accumet $\mathrm{pH}$ meter; Fisher Scientific, Montreal, QC, Canada), and samples were acidified to $\mathrm{pH} 2$ with $50 \% \mathrm{H}_{2} \mathrm{SO}_{4}$ and frozen at $-20^{\circ} \mathrm{C}$ for later determination of VFA and ammonia $\left(\mathrm{NH}_{3}\right)$ concentrations.

Protozoa counts were carried out on rumen content collected $2 \mathrm{~h}$ after the a.m. feeding. Ruminal content (1 L) was strained through 4 layers of cheesecloth and a 5 -mL portion of the rumen fluid strained was preserved using $5 \mathrm{~mL}$ of methyl green formalin-saline solution for protozoa enumeration (Ogimoto and Imai, 1981). Protozoa samples were stored at room temperature in darkness until counting. Protozoa were microscopically enumerated using a counting chamber (Neubauer Improved Bright-Line counting cell, 0.1-mm depth; Hausser Scientific Co., Horsham, PA) and genera were identified as outlined by Dehority (1993). Each sample was counted twice, and if the average of the duplicates differed by more than $10 \%$, the counts were repeated.

\section{Milk Production and Milk Composition}

Cows were milked twice daily in their stalls (0500 and $1700 \mathrm{~h}$ ) and milk yield was recorded at each milking. During the last week of each 28-d period, milk samples were taken from each cow at each milking, stored at $+4^{\circ} \mathrm{C}$ with a preservative (2-bromo-2-nitropropan-1,3diol) and then sent to a commercial laboratory (Valacta Laboratories Inc., Ste-Anne-de-Bellevue, QC, Canada) for analyses of fat, protein, lactose, urea N, and SCC. Milk FA composition was determined on samples pooled on milk yield basis and frozen without preservative at $-80^{\circ} \mathrm{C}$ until analyzed.

\section{Chemical Analyses}

Analyses were performed on each sample in triplicate, and where the coefficient of variation was $>2.5 \%$, the analysis was repeated. Analytical DM content was determined by drying the oven-dried samples at $135^{\circ} \mathrm{C}$ for $2 \mathrm{~h}$, followed by hot weighing (AOAC, 1990; method 930.15). Ash content was determined by incineration at $550^{\circ} \mathrm{C}$ overnight in a muffle furnace (AOAC, 1990; method 942.05) and the OM content was calculated as the difference between 100 and the percentage of ash (AOAC 1990; method 942.05). For the determination of $\mathrm{CP}(\mathrm{N} \times 6.25)$ content, samples were ground using a ball mill (Mixer Mill MM2000; Retsch GmbH, Haan, Germany) to a fine powder and total $\mathrm{N}$ was quantified by thermal conductivity (Leco model FP-428 nitrogen analyzer; Leco Corp., St. Joseph, MI). The concentration of NDF was determined as described by Van Soest et al. (1991) without the use of sodium sulfite and with the inclusion of heat stable $\alpha$-amylase. The ADF content was determined according to AOAC (1990; method 973.18). The NDF and ADF procedures were adapted for use in an Ankom200 Fiber Analyzer (Ankom Technology Corp., Fairport, NY). The concentration of starch was determined colorimetrically according to the procedure of Hall (2000). Ether extract concentration was determined using a Soxlec system HT6 apparatus (Tecator, Fisher Scientific, Montreal, QC, Canada) according to the Association of Official Analytical Chemists method 920.39 (AOAC, 1990). Gross energy content was determined using an adiabatic calorimeter (model 1241; Parr Instrument Co., Moline, IL). Chromium concentration was determined according to the method of Fenton and Fenton (1979). Ruminal $\mathrm{NH}_{3}$ concentration was determined using the method described by Weatherburn (1967) modified for use with a plate reader. Ruminal VFA were quantified using a gas chromatograph (model 5890; HewlettPackard Labs, Palo Alto, CA) with a capillary column $(30-\mathrm{m} \times 0.32-\mathrm{mm}$ i.d., $1-\mu \mathrm{m}$ phase thickness, Zebron ZB-FAAP; Phenomenex Inc., Torrance, CA) and flame ionization detection. The oven temperature was $170^{\circ} \mathrm{C}$ held for $4 \mathrm{~min}$, which was then increased by $5^{\circ} \mathrm{C} / \mathrm{min}$ to $185^{\circ} \mathrm{C}$, and then by $3^{\circ} \mathrm{C} / \mathrm{min}$ to $220^{\circ} \mathrm{C}$, and held at this temperature for $1 \mathrm{~min}$. The injector temperature was $225^{\circ} \mathrm{C}$, the detector temperature was $250^{\circ} \mathrm{C}$, and the carrier gas was helium.

For the analysis of milk FA, methyl esters were prepared by base-catalyzed transmethylation according to the method of Chouinard et al. (1997). Fatty acid analyses were carried out with a gas chromatograph (HP 5890A Series II; Hewlett-Packard Labs) equipped with a 100-m CP-Sil 88 capillary column (i.d., 0.25 
mm; film thickness, $0.20 \mu \mathrm{m}$; Chrompack Nederland BV, Middelburg, the Netherlands) and a flame ionization detector as previously described (Farnworth et al., 2007). Composition of FA in feed samples was analyzed according to the procedure of Sukhija and Palmquist (1988).

\section{Statistical Analyses}

Data were analyzed as a $4 \times 4$ Latin square design using the MIXED procedure of SAS (SAS Institute Inc.). The model included treatment and period as fixed effects and cows as a random effect. The residual effect was initially included in the model but it was removed because it was not significant. For the statistical analysis of ruminal fermentation characteristics $(\mathrm{pH}$, VFA, and $\mathrm{NH}_{3}$ ), sampling time and sampling time $\times$ treatment were added to the model and analyzed as repeated measures using the MIXED procedure of SAS. Protozoa were $\log _{10}$ transformed before analysis using the MIXED procedure of SAS. Linear and quadratic contrasts were used to determine the effect of increasing amounts of LO on response variables. Significance was declared at $P \leq 0.05$ and tendencies at $0.05<P$ $\leq 0.10$.

\section{RESULTS AND DISCUSSION}

\section{DMI and Apparent Total-Tract Digestibility}

Data of DMI and apparent total-tract digestibility are shown in Table 2. The addition of LO to TMR had no effect $(P>0.10)$ on DMI (expressed in kilogram per day or as percentage of $\mathrm{BW}$ ) and digestibility of DM, OM, CP, NDF, NDF, ADF, starch, and gross energy. The effects of unsaturated fat, including LO supplementation on intake and nutrient digestibility, have been variable among studies. For example, Ben Salem et al. (1993) reported no effect of $7 \%$ rapeseed oil supplementation to a grass hay-based diet [60:40 forage:concentrate $(\mathbf{F}: \mathbf{C})$, DM basis $]$ but rapeseed oil decreased $\mathrm{OM}$ and fiber digestibility in cows fed a corn silage-based diet (65:35 F:C, DM basis). In contrast, Martin et al. (2008) observed that supplementing 5.7\% LO to a forage-based diet (65:35 F:C, DM basis) of dairy cows decreased DMI and digestibility of DM, OM, and fiber. Doreau et al. (2009) supplemented 2.6\% LO to a dairy cow diet rich in forage (75:25 F:C, DM basis) and found that LO did not depress DMI nor digestibility of DM, OM, and fiber, when compared with the basal diet. Furthermore, Ueda et al. (2003) reported no difference in daily DMI in cows fed high-forage (65:35 F:C, DM basis) or high-concentrate (35:65 F:C, DM basis) diets and supplemented with $3 \% \mathrm{LO}$, when compared with unsupplemented cows. Likewise, Shingfield et al. (2011) found no effect of 3\% LO supplementation to a corn silage-based diet (60:40 F:C; DM basis) of growing steers on DMI or apparent total-tract digestibility of DM, OM, or fiber. Interestingly, Ueda et al. (2003) reported that fiber and $\mathrm{OM}$ digestibility increased in $3 \%$ LO-supplemented dairy cows fed a high-forage diet, but digestibility of these components decreased when cows were fed a high-concentrate diet. Taken together, these results suggest that the effects of unsaturated fat supplementation, including LO, on DMI and nutrient digestibility vary with the amount of fat added, the source of forage, and the $\mathrm{F}: \mathrm{C}$ ratio of the diet.

\section{Ruminal In Sacco Degradation}

The addition of LO to diets had no effect on the rapidly degradable fraction (a) of the DM of timothy hay, but the slowly degradable fraction $(\mathrm{b})$ tended $(P$ $=0.06)$ to increase linearly with increasing amounts

Table 2. Dry matter intake and apparent total-tract digestibility in lactating cows fed a TMR without supplementation (control, CTL) or supplemented with $2 \%$ (LO2), $3 \%$ (LO3), or $4 \%$ (LO4) linseed oil

\begin{tabular}{|c|c|c|c|c|c|c|c|}
\hline Item & \multicolumn{4}{|c|}{ Diet } & SEM & \multicolumn{2}{|c|}{ Contrast ( $P$-value) } \\
\hline \multicolumn{8}{|l|}{ DMI } \\
\hline$\%$ of BW & 3.3 & 3.2 & 3.09 & 3.1 & 0.10 & 0.25 & 0.92 \\
\hline \multicolumn{8}{|c|}{ Digestibility, $\%$ of intake } \\
\hline DM & 63.8 & 63.5 & 64.0 & 62.6 & 1.90 & 0.75 & 0.78 \\
\hline $\mathrm{NDF}$ & 44.0 & 42.2 & 46.8 & 40.8 & 2.87 & 0.73 & 0.62 \\
\hline $\mathrm{ADF}$ & 48.3 & 45.8 & 49.8 & 42.5 & 2.80 & 0.34 & 0.46 \\
\hline Starch & 85.2 & 84.7 & 84.0 & 85.0 & 1.62 & 0.83 & 0.73 \\
\hline Gross energy & 62.0 & 62.3 & 62.5 & 61.0 & 2.00 & 0.81 & 0.66 \\
\hline
\end{tabular}


Table 3. In sacco degradation kinetic parameters of timothy hay incubated in the rumen of lactating dairy cows fed a TMR without supplementation (control, CTL) or supplemented with 2\% (LO2), 3\% (LO3), or 4\% (LO4) linseed oil

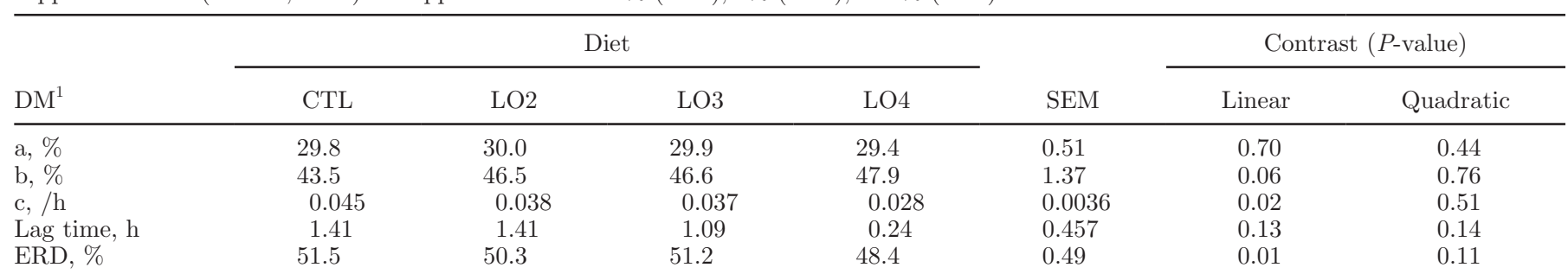

${ }_{\mathrm{i}} \mathrm{a}=$ rapidly degradable fraction; $\mathrm{b}=$ slowly degradable fraction; $\mathrm{c}=$ fractional degradation rate of disappearance of fraction $\mathrm{b} ; \mathrm{ERD}=$ effective ruminal degradability.

of LO in the diet (Table 3). The lag time (L) of DM degradation did not change $(P>0.10)$ with LO supplementation, but the rate of ruminal degradation (c) of DM of timothy hay decreased linearly $(P=0.02)$ as the level of LO increased in the diets. Consequently, the ERD of DM also decreased linearly as the level of LO increased in the diet $(P<0.1)$. Nonetheless, the extent of this decrease was small, ranging between 0.6 to $6 \%$ from the lowest (i.e., $2 \%$ ) to the highest (i.e., 4\%) LO level, respectively.

The results of the in sacco degradation in the present experiment seem to be in contradiction with the lack of effect of LO supplementation on apparent total-tract digestibility (Table 2). In fact, despite the slight decrease in ERD, no change was noted in apparent total-tract digestibility of nutrients, suggesting an increase in postruminal digestion. This hypothesis can be supported by the data from Ueda et al. (2003) who observed an increase in apparent total-tract digestibility of fiber despite decreased ruminal digestion in cows fed a concentrate-based diet and supplemented with LO, suggesting a compensatory digestion at postruminal sites. However, it is also possible that the effects of LO supplementation on ruminal digestion vary with the amount of LO added to the diet. At a level of LO supplementation of $2.6 \%$ in dairy cows (Doreau et al., 2009) and 3\% in growing steers (Shingfield et al., 2011), no effects were observed on ruminal digestion, whereas at higher levels (i.e., $6 \%$ of dietary DM), Ikwuegbu and Sutton (1982) and Broudiscou et al. (1994) reported significant decreases in ruminal digestion.

\section{Ruminal Fermentation Characteristics}

Because there were no interactions between treatment and sampling time for any of the ruminal fermentation parameters measured, only averages over time are presented (Table 4). Ruminal liquor $\mathrm{pH}$ and total VFA concentrations were not affected $(P>0.10)$ when LO was supplemented to diets. Ueda et al. (2003) also reported no effect of LO supplementation on either ruminal liquor $\mathrm{pH}$ or total VFA concentration when they added LO at 3\% to dairy cow forage- and concentrate-based diets. Shingfield et al. (2011) also found similar results when they supplemented 3\% LO to a corn silage-based diet of growing steers. The lack of changes in ruminal $\mathrm{pH}$ and total VFA concentration in our study and the cited studies as well may suggest

Table 4. Ruminal fermentation characteristics of lactating cows fed a TMR without supplementation (control, CTL) or supplemented with $2 \%$ (LO2), 3\% (LO3), or 4\% (LO4) linseed oil

\begin{tabular}{|c|c|c|c|c|c|c|c|}
\hline \multirow[b]{2}{*}{ Item } & \multicolumn{4}{|c|}{ Diet } & \multirow[b]{2}{*}{ SEM } & \multicolumn{2}{|c|}{ Contrast $^{1}$ ( $P$-value $)$} \\
\hline & CTL & $\mathrm{LO} 2$ & LO3 & $\mathrm{LO} 4$ & & Linear & Quadratic \\
\hline $\mathrm{NH}_{3}, \mathrm{~m} M$ & 12.8 & 12.0 & 11.3 & 12.2 & 1.10 & 0.55 & 0.57 \\
\hline Total VFA, mM & 140.6 & 140.0 & 139.7 & 136.2 & 2.60 & 0.32 & 0.51 \\
\hline \multicolumn{8}{|l|}{ VFA, mol/100 mol } \\
\hline Acetate $(\mathrm{A})$ & 61.9 & 61.4 & 61.2 & 62.3 & 0.30 & 0.59 & 0.03 \\
\hline Isobutyrate & 1.15 & 1.22 & 1.24 & 1.25 & 0.01 & 0.01 & 0.34 \\
\hline Valerate & 1.31 & 1.28 & 1.29 & 1.21 & 0.02 & 0.05 & 0.24 \\
\hline Isovalerate & 1.39 & 1.41 & 1.54 & 1.45 & 0.05 & 0.20 & 0.61 \\
\hline Caproate & 0.29 & 0.32 & 0.32 & 0.30 & 0.03 & 0.76 & 0.47 \\
\hline $\mathrm{A}: \mathrm{P}$ & 2.88 & 2.84 & 2.91 & 3.07 & 0.05 & 0.04 & 0.04 \\
\hline
\end{tabular}


Table 5. Total counts and genera distribution of ruminal ciliate protozoa in lactating cows fed a TMR without supplementation (control, CTL) or supplemented with $2 \%$ (LO2), $3 \%$ (LO3), or $4 \%$ (LO4) linseed oil

\begin{tabular}{|c|c|c|c|c|c|c|c|}
\hline \multirow[b]{2}{*}{ Protozoa, $\log _{10} / \mathrm{mL}$} & \multicolumn{4}{|c|}{ Diet } & \multirow[b]{2}{*}{ SEM } & \multicolumn{2}{|c|}{ Contrast ( $P$-value $)$} \\
\hline & CTL & $\mathrm{LO} 2$ & LO3 & $\mathrm{LO} 4$ & & Linear & Quadratic \\
\hline Dasytricha spp. & 1.85 & 2.71 & 0.90 & 3.03 & 0.967 & 0.70 & 0.69 \\
\hline Entodinium spp. & 5.72 & 5.72 & 5.65 & 5.73 & 0.096 & 0.89 & 0.80 \\
\hline Epidinium spp. & 3.27 & 3.77 & 4.03 & 4.74 & 0.796 & 0.25 & 0.75 \\
\hline Eudiplodinium spp. & 2.18 & 2.19 & 3.20 & 3.20 & 0.613 & 0.21 & 0.71 \\
\hline
\end{tabular}

${ }^{1}$ Not detected.

that the level of LO supplementation (i.e., 4\%) was not high enough to affect ruminal metabolism. Indeed, Broudiscou et al. (1994) reported a decrease in total VFA concentration in sheep supplemented with $6 \%$ of LO in a forage-based diet (55:45 F:C).

In the present study, supplementation with increasing amounts of LO caused a quadratic response $(P=$ $0.03)$ in molar proportion of acetate and a linear $(P<$ 0.05 ) decrease in propionate proportion (Table 4). As a consequence, the acetate:propionate ratio also increased linearly $(P=0.04)$ with increasing amounts of $\mathrm{LO}$ in the diet. Supplementation with LO resulted in linear increases $(P<0.05)$ of molar proportions of butyrate and isobutyrate. Valerate molar proportion decreased linearly as the level of LO in the diet increased, but isovalerate remained unaffected by LO supplementation. Caproate proportion did not change $(P<0.05)$ by the addition of LO to diets. However, the extent of changes in molar proportions of VFA noted in this study was minor.

It is generally assumed that supplementation of unprotected and highly unsaturated fats to diets of ruminants decreases the acetate proportion and acetate:propionate ratio in the rumen, with an antimicrobial effect of PUFA-rich oils as one probable explanation for this phenomenon (Jenkins and Jenny, 1992). Previous studies reported a shift in VFA patterns toward proportionally more propionate and less acetate when sheep (Broudiscou et al., 1994) and dairy cows (Ueda et al., 2003) were supplemented with LO. However, other studies reported no change in VFA patterns when dairy cows were fed LO-supplemented diets (Doreau et al., 2009; Shingfield et al., 2011). Again, discrepancy between studies for the effects of LO on VFA patterns may be explained by the source of forage fed. Indeed, despite a similar level of supplementation (i.e., $3 \%$, DM basis), the effect on VFA patterns was not the same when LO was supplemented to a hay-based diet (Ueda et al., 2003) than when it was supplemented to a corn silage-based diet (Doreau et al., 2009). This fact can be corroborated by the observations of Ben Salem et al. (1993) who reported that in dairy cows, acetate and propionate proportions were unaffected when rapeseed oil was added to a hay-based diet, whereas the proportions of these VFA changed when the diet contained corn silage as the major forage source.

In the present study, LO supplementation had no effect $(P>0.05)$ on ruminal ammonia concentration (Table 4). Again, results from previous studies with LO have been variable. Doreau et al. (2009) reported no effect of LO supplementation on ammonia concentration, whereas Ueda et al. (2003) observed greater ruminal ammonia concentration in LO-supplemented dairy cows when compared with control cows. Other studies, reported a decrease in ammonia concentration in sheep supplemented with different levels of LO (Ikwuegbu and Sutton, 1982; Broudiscou et al., 1994).

\section{Ruminal Protozoa Counts}

Little information exists on the effect of supplementing dairy cow diets with LO on total counts and genera distribution of ruminal ciliate protozoa. In the current study, total numbers and the genera distribution of ruminal protozoa were not affected $(P>0.10)$ by LO supplementation to the diets (Table 5).

In general, the addition of lipids to ruminant diets has been found to decrease ruminal protozoal counts and the magnitude of the effect seems to depend on the level of lipid supplementation (Doreau and Ferlay, 1995) and the degree of unsaturation of the lipid source. In vitro incubations have showed that among FA, both linoleic and linolenic acids exert the strongest negative effect on protozoal counts (Hristov et al., 2004; Szumacher-Strabel et al., 2004). Linseed oil seems to have a more negative effect than other sources of lipids, which has been attributed to its high content of linolenic acid (Doreau and Ferlay, 1995).

In the literature, linseed (seeds or oil) supplementation rich in linolenic acid did not affect (Beauchemin 
Table 6. Milk production and milk composition of lactating cows fed a TMR without supplementation (control, CTL) or supplemented with $2 \%$ (LO2), $3 \%$ (LO3), or $4 \%$ (LO4) linseed oil

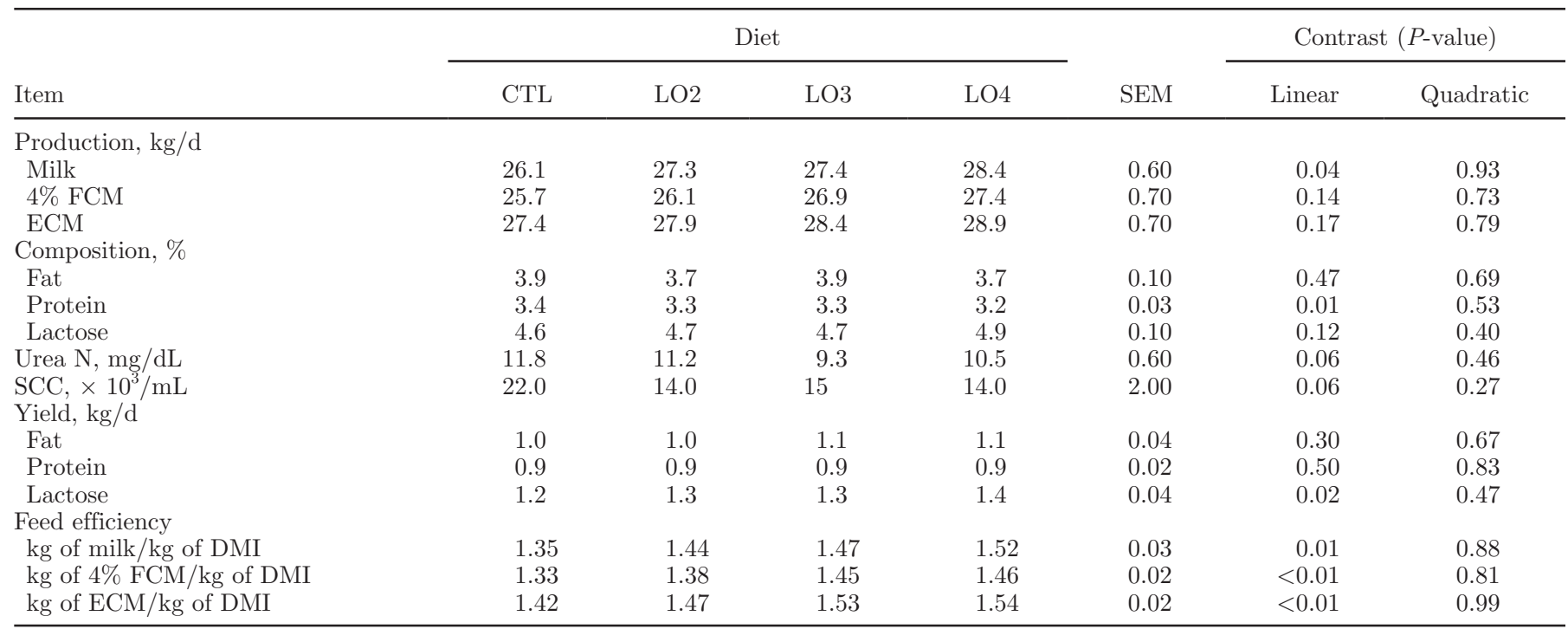

et al., 2009) or decreased (Ikwuegbu and Sutton, 1982; Sutton et al., 1983; Broudiscou et al., 1994) the numbers of ruminal protozoa. For example, Doreau et al. (2009) observed no changes in protozoa numbers in ruminal fluid of cows supplemented with $2.6 \%$ of LO. Conversely, Ikwuegbu and Sutton (1982) reported a linear decrease in total protozoa numbers ranging from 0 to $99 \%$ in sheep supplemented with increasing amounts of LO (i.e., 0 to 6\%; DM basis). Based on these results, it appears that a large amount of LO is required to decrease the numbers of ruminal protozoa.

In addition, an interaction seems to exist between LO supplementation and the basal diet, which causes shifts within the protozoal population. Thus, a $3 \%$ LO supplementation to a concentrate-rich diet (65\%) fed to dairy cows did not alter the numbers of holotrich protozoa Dasytricha spp. and Isotricha spp., but decreased the numbers of Entodiniomorphs, namely Entodinium spp., and the total protozoal counts (Ueda et al., 2003). However, when a $3 \% \mathrm{LO}$ was added to a forage-rich diet (65\%), the numbers of holotrich protozoa increased, but neither Entodinium spp. population nor total protozoal counts changed (Ueda et al., 2003).

\section{Milk Production and Milk Composition}

The results of milk production and milk composition are presented in Table 6 . As the amount of LO in the diet increased, milk production increased linearly $(P$ $=0.04$ ), but the yields of $4 \% \mathrm{FCM}$ and $\mathrm{ECM}$ were unaffected $(P>0.05)$. Feed efficiency, expressed as kilograms of milk, kilograms of $4 \%$ FCM, or kilograms of ECM per kilogram of DMI, increased linearly $(P<$ $0.05)$ with increasing amounts of LO added to diets. Literature data on the effects of LO supplementation of milk production have been variable. Loor et al. (2005) did not observe any effect of $3 \% \mathrm{LO}$ on milk production when added to either forage-based $(65: 35 \mathrm{~F}: \mathrm{C})$ or concentrate-based diets (35:65 F:C) of dairy cows. A higher LO level of supplementation (i.e., $5 \%$ ) in a grass hay-based diet (64:36 F:C, DM basis) did not affect milk production either (Roy et al., 2006). In contrast, $\mathrm{Bu}$ et al. (2007) observed that supplementing 4\% LO to a forage-based diet $(59: 41 \mathrm{~F}: \mathrm{C})$ of dairy cows increased milk production, although it did not affect ECM. On the other hand, Martin et al. (2008) reported that 5.7\% LO supplementation to a corn silage-based diet (65:35 $\mathrm{F}: \mathrm{C})$ decreased milk production.

From the previous studies cited, it appears that changes in milk yield are closely related to the effects of LO on DMI and diet digestibility (see discussion above). Indeed, the decrease in milk production reported in some studies (e.g., Martin et al., 2008) was associated with a depression in DMI and diet digestibility due to disturbances in rumen function caused by a high level of LO intake (i.e., $>5 \%$ of DMI). In contrast, in other studies (e.g., Bu et al., 2007), where LO was supplemented at a level lower than $5 \%$, milk production increased because of a greater DMI.

In the present experiment, adding LO to dairy cow diets did not affect $(P>0.10)$ milk contents of fat and lactose, but decreased linearly $(P=0.01)$ the proportion of milk protein. Yields $(\mathrm{kg} / \mathrm{d})$ of milk fat and protein were not affected $(P>0.10)$ by the addition of 
LO to the diets, but as the level of supplemented LO in the diets increased, milk lactose yield increased linearly $(P=0.02)$. Reported data on the effect of LO supplementation on milk composition has not been consistent. Milk fat content decreased (Flachowsky et al., 2006), increased (Flowers et al., 2008), or did not change (Bu et al., 2007) in cows fed LO-supplemented diets. The effect of vegetable oils on milk protein content has also been variable. Bu et al. (2007) reported no effect of LO addition on milk protein. In contrast, Flowers et al. (2008) observed an increase in milk protein content of grazing cows supplemented with LO. Variability between studies in milk composition response to LO supplementation could be explained by the amount of LO added to the diet but also by the composition of the basal diet. Indeed, Loor et al. (2005) reported that milk protein content decreased in cows fed LO in a high-forage diet, whereas it increased in cows fed LO in a high-concentrate diet. Chilliard et al. (2009) reported that LO supplementation decreased milk fat content when added to low-NDF diet but not to high-NDF diets.

\section{Milk FA Composition}

Results of milk FA composition are shown in Table 7. Feeding increasing levels of LO linearly decreased milk fat content of short- and medium-chain FA (8:0 to 16:0), and increased the proportion of most 18 carbon FA in milk fat. These effects are consistent with the reduction in de novo FA synthesis due to feeding unsaturated oils, which occurs as a result of greater uptake and secretion of dietary or ruminally derived FA (Palmquist et al., 1993). These effects are also in line with the decrease in milk fat content of glycerol observed in the current study. On a weight basis, less glycerol is actually required to esterify long-chain than short-chain FA during milk triglyceride synthesis. The proportions of 15:0 and 17:0 decreased linearly as the amount of LO in the diet increased. The major source of odd-chain FA found in milk fat is long-chain FA synthesized by ruminal bacteria from odd-numbered VFA. However, this rumen microbial synthesis is known to decrease when cows are fed dietary fat because bacteria use preferably preformed FA available in the ruminal milieu (Byers and Schelling, 1988).

The proportion of cis-9,cis-12,cis-15 18:3, the dominant FA in LO, increased as the level of LO increased up to $3 \%$, but no further increase was observed when $4 \%$ of LO was fed (quadratic effect, $P<0.01$ ). This observation is consistent with the quadratic decrease in apparent recovery of dietary cis-9,cis-12,cis-15 18:3 in milk fat. The decrease in transfer efficiency observed with increasing supply of LO could tentatively be explained by (1) an increased efficiency in biohydrogenation with higher supply of free LO in the diet, (2) a lower intestinal digestibility with an increasing amount of cis-9,cis-12,cis-15 18:3 escaping ruminal fermentation as dietary LO supply increased, or (3) a lower efficiency of mammary uptake as the arterial concentration of cis-9,cis-12,cis-15 18:3 increased. In this regard, Loor et al. (2004) observed an increase in intestinal digestibility of cis-9,cis-12,cis-15 18:3 with dietary supplement of LO, which does not support a limitation in absorption capacity. At the level of the mammary gland, Enjalbert et al. (1998) reported that extraction of arterial FA, either nonesterified or in the form of triglycerides, increased with arterial concentration following duodenal infusion of long-chain FA. Finally, Khas-Erdene et al. (2010) observed a quite stable efficiency of transfer to milk of duodenally infused cis-9,cis-12,cis-15 18:3 over a wide range of FA supply. These observations, therefore, provide no support for a postruminal limitation in the transfer efficiency of dietary cis-9,cis-12,cis-15 18:3 to milk fat.

The observed decrease in apparent recovery of dietary cis-9,cis-12,cis-15 18:3 can be explained by the efficiency biohydrogenation process, which has been shown by Loor et al. (2004) to be greater when free LO was added in the diet. In this case (Loor et al., 2004), the extent of ruminal biohydrogenation has been assessed by calculating the proportion of dietary PUFA disappearing during their passage in the rumen (not found in the small intestine). However, this calculation does not provide any information about the efficiency of the overall series of reactions (e.g., the final production of 18:0). According to Harfoot (1981), the biohydrogenation pathway of cis-9,cis-12,cis-15 18:3 involves the production of cis-9,trans-11,cis-15 18:3,trans-11,cis-15 18:2, and trans-11 18:1 or cis-15 18:1, which can all be absorbed and incorporated in milk fat. Among these intermediates, trans-11,cis-15 $18: 2$ and cis-15 18:1 showed a quadratic response to the level of LO supplementation, with the largest increase observed between 3 and $4 \%$ of dietary supplementation (Table 7 ). One may, therefore, speculate that dietary cis-9, cis-12,cis-15 18:3 rapidly undergoes biohydrogenation by being first isomerized to a conjugated triene (cis-9,trans-11,cis-15 18:3), followed by reduction of double bonds at carbons 9 and 11 to yield trans-11,cis-15 18:2 and cis-15 18:1, which accumulate in the rumen as the efficiency of the first step in the pathway increases.

Feeding increasing amounts of LO also increased the proportion of trans-11 18:1 in milk fat, but no quadratic response was observed for this particular biohydrogenation intermediate. This phenomenon can be explained 
Table 7. Milk fat composition (g/100 g) in cows fed a TMR without supplementation (control, CTL) or supplemented with $2 \%$ (LO2), $3 \%$ (LO3), or $4 \%$ (LO4) linseed oil

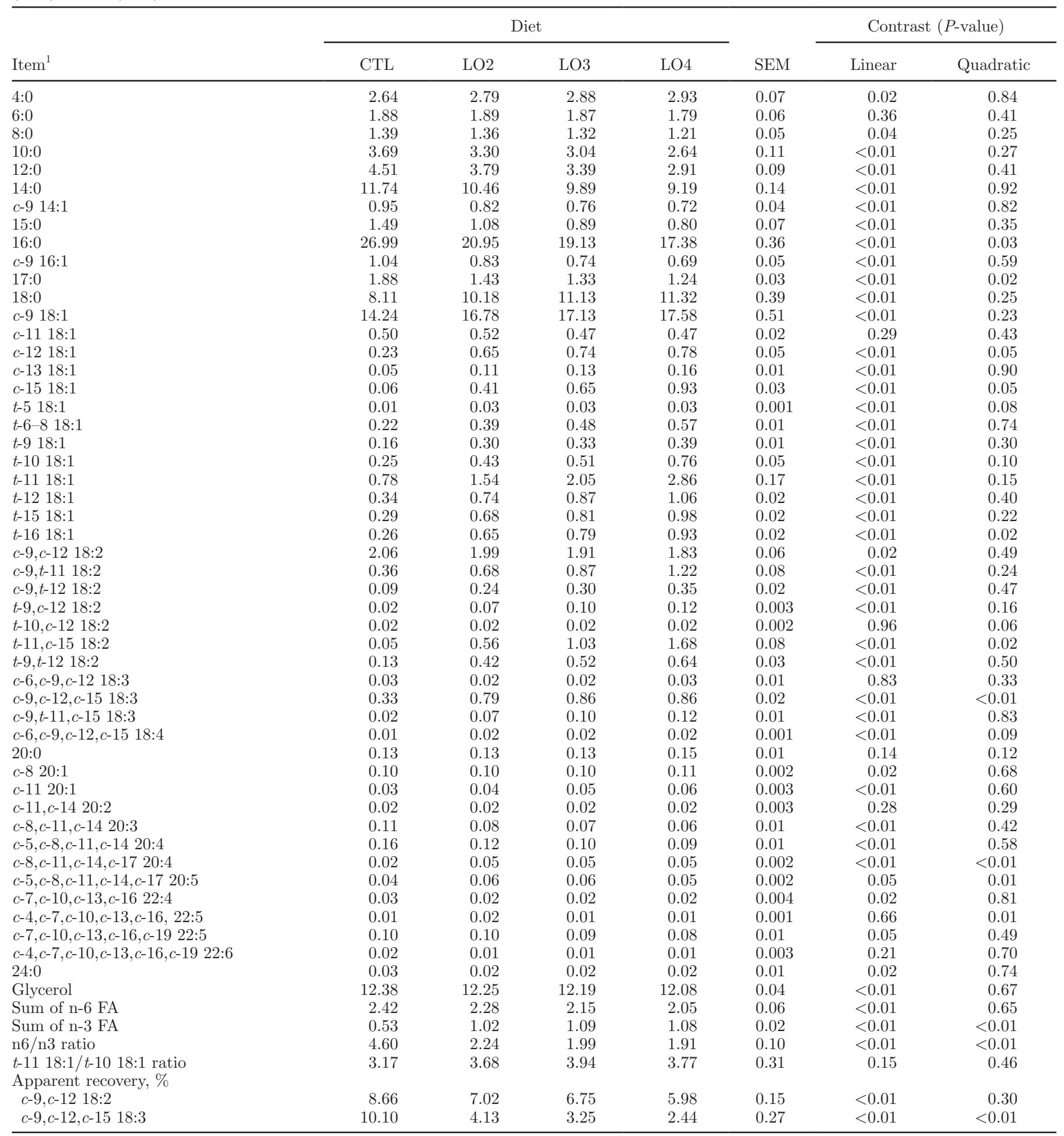

${ }^{1} c=$ cis; $t=$ trans. 
by the fact that trans-11 $18: 1$ is produced during the biohydrogenation of cis-9,cis-12 18:2 and cis-9,cis12,cis-15 18:3 (Harfoot, 1981), which both increased when the diet was supplemented with LO (Table 1). Milk fat content of cis-9,trans-11 18:2 also increased linearly with LO supplementation. It has been established that a great proportion of this CLA isomer found in the milk is produced endogenously in the mammary gland using trans-11 18:1 produced in the rumen as a substrate (Griinari et al., 2000).

In the current study, dietary LO also increased milk fat content of trans-10 18:1. To our knowledge, no evidence exists in the literature showing an extensive production of trans-10 18:1 from dietary cis-9,cis-12,cis-15 18:3 metabolism. Increased proportions of trans-10 18:1 in milk fat could, therefore, be explained by the higher supply of dietary cis-9,cis-12 18:2 (Table 1) or by the overall ruminal unsaturated FA load, as suggested by Lock (2010). Duodenal flow and secretion of trans-10 18:1 in milk fat were shown to be highly dependent on the composition of the basal diet. Feeding LO in a diet rich in starch and based on corn silage as the sole forage increased milk fat content of trans-10 18:1, but did not affect the concentration of trans-11 18:1 (Chilliard et al., 2009). On the contrary, supplemental LO increased trans-11 18:1 without affecting trans-10 18:1 when the diet was based on grass hay rich in fiber (Roy et al., 2006). In the current study, the basal diet was based on a mixture of legume/grass silage and corn silage, which led to an increase in both trans-11 18:1 and trans-10 18:1. However, no alteration of the biohydrogenation pathway was apparent, as the ratio of trans-11 18:1 to trans-10 18:1 remained unchanged between treatments (Table 7). This lack of effect is consistent with similar milk fat content and yield between treatments (Table 6 ), as a shift in this ratio has been associated with an inhibition of milk fat synthesis (Griinari et al., 1998).

After absorption at the intestinal level, cis-9, cis12,cis-15 18:3 goes through a series of reactions involving chain elongation and desaturation (Bernal-Santos et al., 2010), leading to the production of cis-6,cis9,cis-12,cis-15 18:4, cis-8,cis-11,cis-14,cis-17 20:4, cis5,cis-8,cis-11,cis-14,cis-17 20:5, cis-7,cis-10,cis-13,cis16,cis-19 22:5, and cis-4,cis-7,cis-10,cis-13,cis-16,cis-19 22:6. Among these FA, cis-6, cis-9, cis-12,cis-15 18:4 ( $P$ $=0.09)$, cis-8,cis-11,cis-14,cis-17 20:4 $(P<0.01)$, cis5,cis-8,cis-11,cis-14,cis-17 20:5 ( $P=0.01)$, as well as the sum of n-3 FA $(P<0.01)$ showed a quadratic response to increasing amount of LO supplementation, a pattern similar to their precursor cis-9,cis-12,cis-15 18:3 (Table 7). The lack of comparable effect on cis-7,cis-10,cis13,cis-16,cis-19 22:5 and cis-4,cis-7,cis-10,cis-13,cis16, cis-19 22:6 could be explained by their low efficiency of synthesis (last steps in the elongation and desatura- tion process) and their transport as phospholipids in plasma (Tyburczy et al., 2008), which make them less available for mammary uptake. The low availability of these FA in plasma to be taken up by mammary gland may have masked specific treatment effects on their concentration in milk fat.

The greater proportions of n-3 FA combined with a lower proportion of n- 6 FA led to a linear decrease $(P<0.01)$ in the ratio of $\mathrm{n}-6$ to $\mathrm{n}-3 \mathrm{FA}$ in milk fat of cows fed increasing amount of LO (Table 7). Lowering the ratio of n- 6 to n- 3 FA in food products has been recommended to prevent or modulate certain diseases in humans (Connor, 2000). However, the impact of the overall changes in milk FA profile on the nutritive value of milk fat for human remains difficult to assess.

\section{CONCLUSIONS}

Supplementing LO up 4\% to TMR (50:50 F:C, DM basis) did not affect negatively feed digestion, ruminal fermentation efficiency, or milk yield. Feeding LO up to $4 \%$ did not affect total protozoal counts, although species may have shifted within the protozoal populations. Milk FA proportions of n-3 FA increased, whereas those of n-6 FA decreased with the addition of LO in the diet. As a result of changes in these FA, the ratio of n-6 to n-3 was lower in cows supplemented with LO as compared with those fed the control diet. It can be concluded that $4 \%$ LO can be safely supplemented to forage-based diets of dairy cows to enrich milk with potential health-beneficial FA without causing any detrimental effect on digestion, rumen function, or animal performance.

\section{ACKNOWLEDGMENTS}

The authors thank the Dairy and Swine Research Centre (Agriculture and Agri-Food Canada, Sherbrooke, QC, Canada) staff, including L. Croteau (technical support), S. Méthot (help with the statistical analyses), and the barn crew (care of the cows). The authors also thank M. Gingras (Université Laval, Québec, QC, Canada) for FA analyses. G. A. RomeroPérez, F. Hassanat, M. Eugene, and C. Côrtes were recipients of fellowships from the National Science and Engineering Research Council of Canada (Ottawa, ON, Canada). This study was financially supported by Agriculture and Agri-Food Canada.

\section{REFERENCES}

AOAC (Association of Official Analytical Chemists). 1990. Official Methods of Analysis. 15th ed. Association of Official Analytical Chemists, Arlington, VA. 
Beauchemin, K. A., S. M. McGinn, C. Benchaar, and L. Holtshausen. 2009. Crushed sunflower, flax, or canola seeds in lactating dairy cow diets: Effects on methane production, rumen fermentation, and milk production. J. Dairy Sci. 92:2118-2127.

Ben Salem, H., R. Krzeminski, A. Ferlay, and M. Doreau. 1993. Effect of lipid supply on in vivo digestion in cows: Comparison of hay and corn silage diets. Can. J. Anim. Sci. 73:547-557.

Bernal-Santos, G., A. M. O'Donnell, J. L. Vicini, G. F. Hartnell, and D. E. Bauman. 2010. Hot topic: Enhancing omega-3 fatty acids in milk fat of dairy cows by using stearidonic acid-enriched soybean oil from genetically modified soybeans. J. Dairy Sci. 93:32-37.

Broudiscou, L., S. Pochet, and C. Poncet. 1994. Effect of linseed oil supplementation on feed degradation and microbial synthesis in the rumen of ciliate-free and refaunated sheep. Anim. Feed Sci. Technol. 49:189-202.

Bu, D. P., J. Q. Wang, T. R. Dhiman, and J. Liu. 2007. Effectiveness of oils rich in linoleic and linolenic acids to enhance conjugated linoleic acid in milk from dairy cows. J. Dairy Sci. 90:998-1007.

Byers, F. M., and G. T. Schelling. 1988. Lipids in ruminant nutrition. Page 298 in The Ruminant Animal Digestive Physiology and Nutrition. D. C. Church, ed. Prentice-Hall, Englewood Cliffs, NJ.

CCAC (Canadian Council on Animal Care). 1993. Guide to the Care and Use of Experimental Animals. CCAC, Ottawa, ON, Canada.

Chilliard, Y., F. Glasser, A. Ferlay, L. Bernard, J. Rouel, and M. Doreau. 2007. Diet, rumen biohydrogenation and nutritional quality of cow and goat milk fat. Eur. J. Lipid Sci. Technol. 109:828855.

Chilliard, Y., C. Martin, J. Rouel, and M. Doreau. 2009. Milk fatty acids in dairy cows fed whole crude linseed, extruded linseed, or linseed oil, and their relationship with methane output. J. Dairy Sci. 92:5199-5211.

Chouinard, P. Y., J. Lévesque, V. Girard, and G. J. Brisson. 1997. Dietary soybeans extruded at different temperatures: Milk composition and in situ fatty acid reactions. J. Dairy Sci. 80:2913-2924.

Connor, W. E. 2000. Importance of n-3 fatty acids in health and disease. Am. J. Clin. Nutr. 71(Suppl.):171S-175S.

da Silva, D. C., G. T. Santos, A. F. Branco, J. C. Damasceno, R. Kazama, M. Matsushita, J. A. Horst, W. B. R. dos Santos, and H. V. Petit. 2007. Production performance and milk composition of dairy cows fed whole or ground flaxseed with or without monensin. J. Dairy Sci. 90:2928-2936.

Dehority, B. A. 1993. Laboratory Manual for Classification and Morphology of Rumen Ciliate Protozoa. CRC Press Inc., Boca Raton, FL.

Doreau, M., E. Aurousseau, and C. Martin. 2009. Effects of linseed lipids fed as rolled seeds, extruded seeds or oil on organic matter and crude protein digestion in cows. Anim. Feed Sci. Technol. 150:187-196.

Doreau, M., and A. Ferlay. 1995. Effect of dietary lipids on nitrogen metabolism in the rumen: A review. Livest. Prod. Sci. 43:97-110.

Enjalbert, F., M.-C. Nicot, C. Bayourthe, and R. Moncoulon. 1998. Duodenal infusions of palmitic, stearic or oleic acids differently affect mammary gland metabolism of fatty acids in lactating dairy cows. J. Nutr. 128:1525-1532.

Farnworth, E. R., Y. Chouinard, H. Jacques, S. Venkatramanan, A. A. Maf, S. Defnoun, and P. J. H. Jones. 2007. The effect of drinking milk containing conjugated linoleic acid on fecal microbiological profile, enzymatic activity, and fecal characteristics in humans. Nutr. J. 6:15.

Fenton, T. W., and M. Fenton. 1979. An improved procedure for the determination of chromic oxide in feed and feces. Can. J. Anim. Sci. 59:631-634.

Flachowsky, G., K. Erdmann, L. Hüther, G. Jahreis, P. Möckel, and P. Lebzien. 2006. Influence of roughage/concentrate ratio and linseed oil on the concentration of trans-fatty acids and conjugated linoleic acid in duodenal chyme and milk fat of late lactating cows. Arch. Anim. Nutr. 60:501-511.

Flowers, G., S. A. Ibrahim, and A. A. AbuGhazaleh. 2008. Milk fatty acid composition of grazing dairy cows when supplemented with linseed oil. J. Dairy Sci. 91:722-730.
Griinari, J. M., and D. E. Bauman. 1999. Biosynthesis of conjugated linoleic acid and its incorporation into meat and milk in ruminants. Pages 180-200 in Advances in Conjugated Linoleic Acid Research. M. P. Yurawecz, M. M. Mossoba, J. K. G. Kramer, M. W. Pariza, and G. J. Nelson, ed. AOCS Press, Champaign, IL.

Griinari, J. M., B. A. Corl, S. H. Lacy, P. Y. Chouinard, K. V. V. Nurmela, and D. E. Bauman. 2000. Conjugated linoleic acid is synthesized endogenously in lactating dairy cows by Delta-9 desaturase. J. Nutr. 130:2285-2291.

Griinari, J. M., D. A. Dwyer, M. A. McGuire, D. E. Bauman, D. L. Palmquist, and K. V. V. Nurmela. 1998. Trans-octadecenoic acids and milk fat depression in lactating dairy cows. J. Dairy Sci. 81:1251-1261.

Hall, M. B. 2000. Neutral detergent-soluble carbohydrates nutritional relevance and analysis. Extension Institute of Agricultural Sciences, University of Florida, Gainesville.

Harfoot, C. G. 1981. Lipid metabolism in the rumen. Page 21 in Lipid Metabolism in Ruminant Animals. W. W. Christie, ed. Pergamon Press, New York, NY.

Hristov, A. N., M. Ivan, and T. A. McAllister. 2004. In vitro effects of individual fatty acids on protozoal numbers and on fermentation products in ruminal fluid from cattle fed a high-concentrate, barley-based diet. J. Anim. Sci. 82:2693-2704.

Hulshof, K. F. A. M., M. A. van Erp-Baart, M. Anttolainen, W. Becker, S. M. Church, C. Couet, E. Hermann-Kunz, H. Kesteloot, T. Leth, I. Martins, O. Moreiras, J. Moschandreas, L. Pizzoferrato, A. H. Rimestad, H. Thorgeirsdottir, J. M. N. van Amelsvoort, A. Aro, A. G. Kafatos, D. Lanzmann-Petithory, and G. van Poppel. 1999. Intake of fatty acids in Western Europe with emphasis on trans fatty acids: The TRANSFAIR study. Eur. J. Clin. Nutr. 53:143-157.

Ikwuegbu, O. A., and J. D. Sutton. 1982. The effect of varying the amount of linseed oil supplementation on rumen metabolism in sheep. Br. J. Nutr. 48:365-375.

Jenkins, T. C. 1993. Lipid metabolism in the rumen. J. Dairy Sci. $76: 3851-3863$.

Jenkins, T. C., and B. F. Jenny. 1992. Nutrient digestion and lactation performance of dairy cows fed combinations of prilled fat and canola oil. J. Dairy Sci. 75:796-803.

Joyce, T., A. J. Wallace, S. N. McCarthy, and M. J. Gibney. 2009. Intakes of total fat, saturated, monounsaturated and polyunsaturated fatty acids in Irish children, teenagers and adults. Public Health Nutr. 12:156-165.

Khas-Erdene, Q., J. Q. Wang, D. P. Bu, L. Wang, J. K. Drackley, Q. S. Liu, G. Yang, H. Y. Wei, and L. Y. Zhou. 2010. Responses to increasing amounts of free $\alpha$-linolenic acid infused into the duodenum of lactating dairy cows. J. Dairy Sci. 93:1677-1684.

Lock, A. 2010. Update on dietary and management effects on milk fat. Pages 15-26 in Proc. Tri-State Dairy Nutr. Conf., Fort Wayne, IN. The Ohio State University, Columbus.

Loor, J. J., A. Ferlay, A. Ollier, M. Doreau, and Y. Chilliard. 2005. Relationship among trans and conjugated fatty acids and bovine milk fat yield due to dietary concentrate and linseed oil. J. Dairy Sci. 88:726-740.

Loor, J. J., K. Ueda, A. Ferlay, Y. Chilliard, and M. Doreau. 2004. Biohydrogenation, duodenal flow, and intestinal digestibility of trans fatty acids and conjugated linoleic acids in response to dietary forage:concentrate ratio and linseed oil in dairy cows. J. Dairy Sci. 87:2472-2485.

Martin, C., J. Rouel, J. P. Jouany, M. Doreau, and Y. Chilliard. 2008. Methane output and diet digestibility in response to feeding dairy cows crude linseed, extruded linseed, or linseed oil. J. Anim. Sci. $86: 2642-2650$

McDonald, I. 1981. A revised model for the estimation of protein degradability in the rumen. J. Agric. Sci. 96:251-252.

NRC. 2001. Nutrient Requirements of Dairy Cattle. National Academy Press, Washington, DC.

Ogimoto, K., and S. Imai. 1981. Page 158 in Atlas of Rumen Microbiology. Japan Sci. Soc. Press, Tokyo, Japan. 
Palmquist, D. L., A. D. Beaulieu, and D. M. Barbano. 1993. Feed and animal factors influencing milk fat composition. J. Dairy Sci. $76: 1753-1771$

Roy, A., A. Ferlay, K. J. Shingfield, and Y. Chilliard. 2006. Examination of the persistency of milk fatty acid composition responses to plant oils in cows given different basal diets, with particular emphasis on trans- $\mathrm{C}_{18: 1}$ fatty acids and isomers of conjugated linoleic acid. Anim. Sci. 82:479-492.

Shingfield, K. J., M. R. F. Lee, D. J. Humphries, N. D. Scollan, V. Toivonen, D. E. Beever, and C. K. Reynolds. 2011. Effect of linseed oil and fish oil alone or as an equal mixture on ruminal fatty acid metabolism in growing steers fed maize silage-based diets. J. Anim. Sci. 89:3728-3741.

Sukhija, P. S., and D. L. Palmquist. 1988. Rapid method for determination of total fatty acid content and composition of feedstuffs and feces. J. Agric. Food Chem. 36:1202-1206.

Sutton, J. D., R. Knight, A. B. McAllan, and R. H. Smith. 1983. Digestion and synthesis in the rumen of sheep given diets supplemented with free and protected oils. Br. J. Nutr. 49:419-432.
Szumacher-Strabel, M., S. A. Martin A. Potkański, A. Cieślak, and J Kowalczyk. 2004. Changes in fermentation processes as the effect of vegetable oil supplementation in in vitro studies. J. Anim. Feed Sci. 13(Suppl. 1):215-218.

Tyburczy, C., A. L. Lock, D. A. Dwyer, F. Destaillats, Z. Mouloungui, L. Candy, and D. E. Bauman. 2008. Uptake and utilization of trans octadecenoic acids in lactating dairy cows. J. Dairy Sci. 91:3850-3861.

Ueda, K., A. Ferlay, J. Chabrot, J. J. Loor, Y. Chilliard, and M. Doreau. 2003. Effect of linseed oil supplementation on ruminal digestion in dairy cows fed diets with different forage:concentrate ratios. J. Dairy Sci. 86:3999-4007.

Van Soest, P. J., J. B. Robertson, and B. A. Lewis. 1991. Methods for dietary fiber, neutral detergent fiber, and nonstarch polysaccharides in relation to animal nutrition. J. Dairy Sci. 74:3583-3597.

Weatherburn, M. W. 1967. Phenol-hypochlorite reaction for determination of ammonia. Anal. Chem. 39:971-974. 